\title{
Komórki macierzyste raka nerki - pochodzenie i znaczenie
}

\section{STRESZCZENIE}

$\mathbf{R}$ aki stanowią 85\% guzów nerki. W Polsce każdego roku raka nerki rozpoznaje się u prawie czterech tysięcy osób, a ponad dwa tysiące $\mathrm{z}$ nich umiera. Znanych jest kilka rodzajów raka nerki, spośród których najczęściej występującym jest rak jasnokomórkowy (ang. clear cell Renal Cell Carcinoma; ccRCC), który występuje w 80-90 proc. wszystkich przypadków raka nerki. ccRCC należy do nowotworów opornych na leczenie chemiczne i radioterapię. Coraz więcej danych wskazuje, iż masa nowotworu powstaje $\mathrm{w}$ efekcie podziałów i różnicowania niewielkiej liczby komórek zwanych komórkami macierzystymi nowotworu (komórkami inicjującymi guz, ang. cancer stem cells - CSC). CSC są nie tylko odpowiedzialne za rozwój nowotworu, ale także za wznowę, progresję choroby i jej oporność na chemio-i radioterapię. W pracy omówiono pochodzenie CSC w raku nerki, ze szczególnym uwzględnieniem podtypu jasnokomórkowego.

\section{WSTEP}

Co roku rak nerki (ang. Renal Cell Cancer, RCC) jest diagnozowany u około 270000 osób na świecie, z czego u prawie $80 \%$ pacjentów to podtyp jasnokomórkowy RCC. Umieralność na raka jasnokomórkowego nerki (ccRCC) wynosi około 50\% [1]. Rak jasnokomórkowy nerki znajduje się w pierwszej dziesiątce najczęściej rozpoznawanych nowotworów na świecie i w Polsce. Tylko w 40\% przypadków diagnozuje się go w stadiach wczesnych (guz pT1-T2), w 25\% przypadków rozpoznaje się chorobę w stadium znacznego zaawansowania miejscowego (guz pT3), a u ponad 30\% chorych nowotwór ten jest wykrywany w stadium choroby przerzutowej (ang. metastatic Renal Cell Carcinoma, mRCC). Dodatkowo, mimo leczenia poprzez nefrektomię (resekcję nerki), u 30\% pacjentów, którzy pierwotnie byli zdiagnozowani w stadium zaawansowania M0, rozwinie się choroba przerzutowa (M1). Raka ccRCC charakteryzuje wysoka oporność na chemioterapię i radioterapię, co negatywnie wpływa na możliwości terapeutyczne i przeżywalność pacjentów. Przeżywalność przy nieleczonym przerzutowym raku nerki wynosi ok. 5 miesięcy, a 29\% chorych przeżyje 12 miesięcy [2]. W związku z dużą opornością ccRCC na chemioterapię oraz radioterapię, wynikającą z mechanizmów molekularnych, takich jak zjawisko oporności wielolekowej i wieloczynnikowej oporności wielolekowej, leczenie mRCC opierało się do niedawna wyłącznie na immunoterapii cytokinami - interleukiną 2 (IL-2) i interferonem alfa-2a (IFN a-2a) [3]. Odkrycia z zakresu biologii molekularnej i immunologii pozwoliły w ostatnich 10 latach na opracowanie szeregu nowych terapii celowanych i nowej generacji immunoterapii.

Ważnym elementem patogenezy ccRCC jest inaktywacja genu von HippelLindau (VHL) w efekcie mutacji lub hipermetylacji promotora genu. Białko VHL jest supresorem nowotworów. Inaktywacja, mutacja lub utrata obydwu alleli (VHL -/-) promuje rozwój nowotworu. Skutkiem utraty funkcji lub braku ekspresji białka VHLjest aktywacja szlaku czynnika aktywowanego hipoksją - HIF (ang. hypoxia-inducible factor) oraz kompleksu mTOR (ang. mammalian target of rapamycin) [4]. W 45\% przypadków ccRCC znajdowana jest również mutacja genów modyfikacji chromatyny oraz naprawy DNA, takich jak PBMR1 (ang. Polybromo-1) oraz BAP1 (ang. BRCA1 associated protein-1), które również są supresorem nowotworowym. Gen PBMR1 znajduje się na tym samym chromosomie i tym samym ramieniu co gen $V H L$ - zwiększa to prawdopodobieństwo delecji obu genów w wyniku jednego uszkodzenia chromosomu. Innymi częstymi mutacjami opisywanymi w RCC są mutacje w genach SETD2 (ang. SET Domain Containing 2), MET (ang. mesenchymal-epithelial transition factor) i MTOR (ang. Mechanistic Target Of Rapamycin Kinase). Badania genetyki RCC doprowadziły do opracowania terapii celowanych - antyangiogennych. Obecnie stosowanymi na świecie lekami w celowanej terapii antyangiogennej (głównie) jasnokomórko-

Podziękowania: Praca została sfinansowana z funduszu Narodowego Centrum Nauki, granty numer: NCN 2011/01/B/NZ5/02822, 2014/13/B/NZ1/04010 oraz funduszy badań własnych IMDiK.

\section{dr Łukasz Szymański ${ }^{1,2 \& a,}$} mgr Igor Helbrecht ${ }^{1,2 \&}$, dr Michał Fiedorowicz ${ }^{3 \rrbracket}$, dr Damian Matak ${ }^{1,4,}$ prof. dr hab. Ewa Bartnik ${ }^{2,5}$, prof. dr hab. Paweł Golik ${ }^{2,5}$, prof. dr hab. Cezary Szczylik ${ }^{1,4, b, c}$,

\section{dr hab. Anna M. Czarnecka ${ }^{1, d, e}$}

${ }^{1}$ Klinika Onkologii, Wojskowy Instytut Medyczny, Warszawa

${ }^{2}$ Instytut Genetyki i Biotechnologii, Wydział Biologii, Uniwersytet Warszawski, Warszawa ${ }^{3}$ Instytut Medycyny Doświadczalnej i Klinicznej im. M. Mossakowskiego PAN, Warszawa ${ }^{4}$ Studium Medycyny Molekularnej, Warszawski Uniwersytet Medyczny, Warszawa

${ }^{5}$ Instytut Biochemii i Biofizyki, Polska Akademia Nauk, Warszawa

\&autorzy w tym samy stopniu pracowali nad manuskryptem

aaktualny adres: Zakład Ochrony Mikrofalowej, Wojskowy Instytut Higieny i Epidemiologii im. gen. Karola Kaczkowskiego, Warszawa baktualny adres: Klinika Onkologii, Europejskie Centrum Zdrowia, Otwock

caktualny adres: Centrum Medyczne Kształcenia Podyplomowego, Warszawa

daktualny adres: Instytut Medycyny Doświadczalnej i Klinicznej im. M. Mossakowskiego

PAN, Warszawa

eaktualny adres: Klinika Nowotworów Tkanek Miękkich, Kości i Czerniaków, Centrum Onkologii - Instytut im. Marii Skłodowskiej-Curie, Warszawa

๑autor korespondencyjny: mfiedorowicz@ imdik.pan.pl

https://doi.org/ 10.18388/pb.2019_250

Słowa kluczowe: rak nerki, komórki macierzyste, CD105, CD133

Najważniejsze skróty: ccRCC - rak jasnokomórkowy nerki; CSC - nowotworowe komórki macierzyste; CTC - krążące komórki nowotworowe; EMT - przemiana epitelialno-mezenchymalna; MET - przemiana mezenchymalno-epitelialna; RCC - rak nerki 
wego raka nerki są sorafenib, sunitinib, pazopanib, aksitynib, kabozantynib, lenwatynib, bewacyzumab, ewerolimus i temsirolimus. W Polsce program lekowy NFZ pozwala na leczenie sunitynibem, sorafenibem, pazopanibem, aksytynibem, ewerolimusem, kabozantynibem $[5,6]$.

Dotychczasowe terapie i diagnozy raka opierają się na założeniu, że masa guza składa się z komórek o podobnym potencjale wzrostowym, histopatologii i biochemii. Nowotwory składają się z niejednorodnej populacji komórek o różnym stadium zróżnicowania, co zostało również udowodnione w ccRCC [7]. Wielu badaczom nowotwór w swej budowie przypomina zdrową tkankę [8]. W masie guza znajdują się komórki o wyższym potencjale regeneracyjnym i stąd też wziął się pomysł, aby nazwać je macierzystymi. Komórki macierzyste raka stanowią jego niewielki procent. Przeważającą większość stanowią komórki o znikomej zdolności do odtworzenia guza czy przerzutowania [9]. Z podobną proporcją mamy do czynienia w zdrowej tkance. Prowadzi to do konkluzji, że dotychczasowe terapie nowotworów oparte były na złych założeniach i skierowane na najmniej inwazyjną, acz najliczniejszą część guza, czyli komórki somatyczne nowotworu [10]. Postulowane potencjalne nowe metody leczenia RCC zakładają specyficzną eliminację komórek macierzystych RCC lub zmuszenie tych komórek do różnicowania w bardziej podatne na konwencjonalne terapie komórki somatyczne nowotworu [11].

\section{KOMÓRKI MACIERZYSTE RAKA I ICH WPEYW NA ROZWÓJ NOWOTWORU}

Komórki macierzyste to niezróżnicowane komórki, które charakteryzują się zdolnością do samoodnowy podczas kolejnych podziałów komórkowych oraz posiadają zdolność różnicowania w szerokie spektrum wyspecjalizowanych komórek. Komórki te charakteryzują się aktywacją szlaków sygnałowych takich białek jak: Notch, Hedgehog, WNT (ang. int-1/wingless)/ $\beta$-katenina, JAK/STAT (ang. Janus kinase/Signal Transducer and Activator of Transcription protein) oraz NFkB (ang. Nuclear factor- $\kappa B$ ). Komórki progenitorowe natomiast są wczesnymi potomkami komórek macierzystych, które mogą różnicować się w jedną lub więcej linii komórkowych, ale nie potrafią zachować zdolności do różnicowania i nieprzerwanej samoodnowy [12]. Komórki macierzyste mogą dzielić się symetrycznie, na dwie komórki macierzyste, lub asymetrycznie, tworząc komórkę macierzystą i komórkę progenitorową - utrzymując dzięki temu stałą populację komórek macierzystych.

Termin nowotworowe komórki macierzyste (ang. cancer stem cells, CSC) jest najczęściej stosowany w literaturze $\mathrm{i}$ jest stosowany również przez nas w tej pracy, ale wywołuje pewne kontrowersje. Termin ten zdaniem części badaczy sugeruje pochodzenie CSC od somatycznych komórek macierzystych (ang. adult stem cells), przy jednoczesnym reprezentowaniu przez nie wyraźnie odmiennej subpopulacji różniącej się od pozostałych komórek nowotworowych. Założenia te nie zostały jednoznacznie potwierdzone i dlatego termin „nowotworowe komórki macierzyste” jest przez niektórych autorów uznawany za nieprawidłowy. CSC moga natomiast powstawać poprzez odróżnicowanie komórek dojrzałych w procesie przejścia nabłonkowo-mezenchymal- nego (ang. epithelial-to-mesenchymal transition, EMT). Inna, szeroko używana nazwa, to komórki inicjujące rozwój guza (ang. tumor initiating cells, TIC), wydaje się także być niewystarczająco precyzyjna [13]. Obecnie nie jest bowiem możliwe określenie, które komórki zaindukowały rozwój guza in vivo, a można jedynie stwierdzić, jaka subpopulacja komórek jest w stanie odtworzyć guz po wszczepieniu zwierzętom o obniżonej odporności (np. myszy bezgrasicze). Kolejny termin opisujący te komórki to komórki macierzystoidalne (ang. stemloid), który ma sugerować podobieństwo nowotworowych komórek macierzystych i somatycznych komórek macierzystych, ale też wskazywać, że nie są to te same rodzaje komórek [14]. Komórki propagujące guza (ang. tumor propagating cells), komórki inicjujące przerzuty (ang. metastasis initiating cells) oraz nowotworowe komórki podobne do macierzystych (ang. tumor stem-like cells, cancer stem cell-like cells) to kolejne określenia opisujące udział tych komórek w rozwoju nowotworu, które z kolei nie sugerują ich pochodzenia od somatycznych komórek macierzystych, a opisujące istotne cechy biologiczne tych komórek [15]. W literaturze nazwy te stosowane są zamiennie, zależnie od ustaleń konkretnej grupy badawczej, a poszukując kompletnych danych dla danego nowotworu konieczne jest śledzenie literatury dotyczącej wszystkich tych określeń.

CSC wraz z innymi komórkami nowotworowymi, tworzą także populację krążących komórek nowotworowych (ang. circulating tumor cells, CTC), które są odpowiedzialne za powstawanie przerzutów [16]. Proces przerzutowania można bowiem podzielić na trzy etapy: 1) Inwazja macierzy zewnątrzkomórkowej przez komórki nowotworowe, 2) Penetracja ściany naczyń krwionośnych przez komórki nowotworowe, 3) Migracja z naczyń do tkanek i kolonizacja nowej niszy przez komórki propagujące guz [15]. Poziom CTC we krwi pacjenta zależy od rodzaju i stopnia zaawansowania choroby (wielkości guza pierwotnego, całkowitej masy nowotworu, wielkości i ilości przerzutów i in.) i waha się pomiędzy 1-10 komórek na ml krwi, co oznacza, że liczba krążących komórek nowotworowych w całym ciele wynosi jednoczasowo między 4000 a 50 000. Zastanawiające może być, dlaczego przy takiej wysokiej liczbie krążących komórek nowotworowych powstaje stosunkowo niewiele ognisk przerzutowych. Tłumaczy się to tym, że większość CTC nie jest $\mathrm{w}$ stanie przeżyć $\mathrm{w}$ nowym mikrośrodowisku zdrowych organów, które wyjściowo nie promuje ich proliferacji. Ogniska przerzutowe mogą powstawać tylko w przypadku, gdy CSC znajdują się w sprzyjającej niszy i będą eksprymować geny umożliwiające im przeżycie, połączenie z macierzą zewnątrzkomórkową organu docelowego przerzutu, a także ucieczkę przed układem odpornościowym [17].

\section{POCHODZENIE NOWOTWOROWYCH KOMÓREK MACIERZYSTYCH}

Pochodzenie CSC, jak wspomniano wyżej, nie zostało w pełni wyjaśnione. Istnieją dwie główne hipotezy wyjaśniające powstawanie komórek CSC. Pierwsza z nich to koncepcja rezydujących komórek macierzystych. Zgodnie z tą koncepcją tkankowe komórki macierzyste, bądź progenitorowe, podczas życia organizmu i kolejnych podziałów mitotycznych akumulują mutacje, które prowadzą do zaburzeń 
biologii komórki i do powstania komórki nowotworowej macierzystej [18]. Badania in vitro i in vivo sugerują, że zdrowe komórki macierzyste mogą transformować w CSC [19]. W transformacji komórek macierzystych do CSC mają brać udział szlaki sygnałowe takie jak Hedgehog, Notch, Bmi1 (ang. Polycomb complex protein BMI-1), Wnt, PTEN (ang. Phosphatase and tensin homolog), Shh (ang. Sonic hedgehog) i Hox $[20,21]$. Wyraźne podobieństwo pomiędzy zdrowymi komórkami macierzystymi a CSC, takie jak zdolność do samoodnowy, różnicowania się w różne subpopulacje komórkowe, oraz oporność na chemioterapię, radioterapię i terapie celowane, również przemawia za poprawnością tej hipotezy.

Druga koncepcja wyjaśniająca źródło CSC to przemiana epitelialno-mezenchymalna (ang. epithelial-mesenchymal transition, EMT) komórek nowotworowych. Jest to koncepcja według której CSC pochodzą ze zróżnicowanych komórek określonej tkanki, które w wyniku mutacji uzyskały cechy macierzystości odróżnicowując [22]. Według tego modelu CSC powstają z przemiany nowotworowych komórek epitelialnych do niespolaryzowanych komórek mezenchymalnych o cechach komórek macierzystych [23]. Możliwość taką potwierdzają doświadczenia z indukowanymi komórkami pluripotencjalnymi [24]. EMT pozwala dodatkowo komórkom migrować do innych lokalizacji, w których zachodzi proces przemiany mezenchymalno-epitelialnej (ang. mesenchymal-epithelial transition, MET), co decyduje o zdolności do inicjowania przerzutów i jest regulowane przez szlaki sygnałowe TGF $\beta$ (ang. transforming growth factor beta 1), Wnt, FGF (ang. fibroblast growth factor), Hedgehog i Notch $[25,26]$. Wymienione szlaki sygnałowe biorą udział w aktywacji czynników transkrypcyjnych takich jak: SNAIL (ang. snail [Drosophila homolog] family transcriptional repressor 1) i TWIST (ang. twist basic helix-loop-helix transcription factor 1), co z kolei zmniejsza poziom ekspresji E-kadheryny, a zwiększa wimentyny i w komórkach aktywuje program transkrypcyjny komórek macierzystych z ekspresją genów macierzystości takich jak Oct-4 i Nanog [23].

Mechanizmy molekularne przemiany EMT w guzach nowotworowych nie są obecnie do końca scharakteryzowane, ale biorąc pod uwagę udział w obu procesach szlaków przekazywania sygnału zależnych od Wnt oraz TGF- $\beta$ można podejrzewać, że embrionalne i nowotworowe EMT przebiegają podobnie [27]. W patogenezie raka nerki szczególną rolę odgrywa czynnik TNF-a (ang. tumor necrosis factor alpha). Jako czynnik antynowotworowy TNF-a jest naturalnie produkowany przez zaktywowane makrofagi. Mimo że jego wysoka ekspresja skutkuje aktywacją procesów przeciwnowotworowych, to niska ekspresja w komórkach nowotworu stymuluje jego wzrost i rozwój. Zawartość TNF-a w osoczu koreluje $\mathrm{z}$ pogarszającym się stanem pacjenta, wzrostem masy nowotworu i rośnie wraz ze wzrostem przerzutów RCC. Efektem komórkowym działania TNF-a w RCC jest spadek ekspresji typowo nabłonkowej E-kadheryny, a wzrost mezenchymalnej wimentyny, co jest zjawiskiem typowym dla EMT. Może to oznaczać, iż TNF-a jest induktorem EMT. Co więcej, pobudzane przez TNF-a komórki RCC łatwiej tworzą sfery komórkowe 3D, a więc potencjalne nowe guzy. Blokada ścieżki sygnałowej rozpoczętej przez TNF-a powoduje wyciszenie EMT w hodowlach komórek RCC, a to oznacza, że TNF-a jest ważnym czynnikiem $\mathrm{w}$ tym procesie, a co za tym idzie i w karcynogenezie RCC [28]. Zgodnie z omawianą koncepcją procesy MET i EMT zachodząc w tkance nowotworowej, w tym RCC, mają istotny wpływ na rozwój choroby i oporności na terapie przeciwnowotworowe, $\mathrm{w}$ tym terapie celowane stosowane w RCC jak sunitynib, sorafenib czy ewerolimus [29].

Niezależnie od dwóch powyższych hipotez, komórki macierzyste raka nerki (RCC-CSC) pochodzą z tkanki nabłonkowej proksymalnych kanalików nerkowych. Komórki RCC powstałego z tkanki nabłonkowej kanalików nerkowych cechują się opornością na chemioterapię i radioterapię oraz mają wysoki potencjał angiogenny. Co istotne, udowodniono już, że komórki RCC uwalniając egzosomy, poprzez zawarte w nich cytokiny indukują przeprogramowanie sąsiednich komórek tak, aby działały promująco na tworzenie się guza [30-32]. Egzosomy wydzielane przez z RCC-CSC o fenotypie CD105+ mogą modyfikować mikrośrodowisko guza, indukować angiogenezę i sprzyjać powstawaniu niszy, w której może dochodzić do uwalniania i osadzania się kolejnych komórek przerzutujących [33]. Egzosomy te zawierają liczne mRNA oraz miRNA, lncRNA, czy circRNA indukujące angiogenezę $\mathrm{w}$ guzach przerzutowych RCC. Po wstrzyknięciu myszom SCID, egzosomy te stymulują także wzrost komórek endotelialnych oraz nowych naczyń krwionośnych. Wstrzykiwanie do krwioobiegu egzosomów z komórek CD105+ powoduje w efekcie znaczne zwiększenie liczby ognisk przerzutowych w płucach w modelu mysim (myszy SCID). Porównanie RNA obecnego w egzosomach pochodzacych $\mathrm{z}$ hodowli CSC i pozostałych komórek nowotworowych guza wykazało zwiększoną obecność transkryptów białek pro-angiogennych: VEGF (ang. vascular endothelial growth factor A), FGF, angiopoetyny 1, MMP2 (ang. matrix metallopeptidase 2) oraz MMP9 [33] w wypadku egzosomów z CSC. Egzosomy podane do hodowli RCC mogą zaindukować ekspresję białek CXCR4 i MMP-9 w komórkach 786-O z guza pierwotnego ccRCC [34]. Nowsze badania pokazują, że egzosomy wydzielane przez komórki CD105+ zawierają białka, mikro-RNA i mRNA, które mogą być przenoszone (endocytoza) do komórek biorców i wywoływać fenotypowe i epigenetyczne zmiany prowadzące do progresji nowotworu a także ucieczki immunologicznej. Poprzez egzosomy komórki CD105+ zakłócają różnicowanie monocytów - utrzymywana jest ekspresja markera CD14, a jednocześnie komórki nie nabywają markerów aktywacji, takich jak CD83 i CD40, czy markerów CD80, CD86 lub CD1a, a4 integryny $\alpha 4$ oraz CD54. Podobnie, ekspresja cząsteczki prezentującej antygen HLA-DR jest znacząco niższa w obecności CSC CD105 +. W efekcie monocyty te nie są w stanie indukować odpowiedzi komórek T CD3+ i ich aktywacji, co chroni komórki RCC przed eliminacją poprzez układ odpornościowy.

\section{KOMÓRKI MACIERZYSTE ZDROWEJ NERKI}

Zdrowa tkanka nerki zawiera komórki zdolne do proliferacji, formowania sfer i przejawiające inne cechy macierzystości - komórki macierzyste zdrowej nerki (ang. renal stem cells, RSC). Pierwszy raz wyizolowano te komórki z nerek dorosłych szczurów używając warunków hodowli komórkowej dla, znanej wcześniej, hodowli komórek progenitoro- 
wych pochodzących ze szpiku kostnego. Komórki te eksprymowały wimentynę i CD80 (thy1.1), ale nie eksprymowały cytokeratyny. Większość tych komórek eksprymowała natomiast białko powierzchniowe CD44. Na komórkach RSC nie obserwowano ekspresji SSEA-1, CD-11b, CD45, CD133, CD106, MHC klasy I i II, CD31, oraz NCAM. Komórki te hodowane w obecności czynnika wzrostu fibroblastów 2 (FGF2), TGF- 32 oraz czynnika hamującego białaczkę (ang. leukemia inhibitory factor, LIF) formowały sfery komórkowe i eksprymowały cytokeratynę. W obecności VEGF zyskiwały morfologię nabłonkową i eksprymowały m. in. CD105. Komórki te były zdolne do proliferacji, w opisanych powyżej warunkach restrykcji czynników wzrostowych, co odrózniało je od zróżnicowanych komórek nerki [35].

Ludzkie komórki progenitorowe nerki zostały wyizolowane z kory usuniętych chirurgicznie zdrowych fragmentów nerek. Komórki CD133+ zostały wyizolowane z frakcji tubularnej metodą sortowania magnetycznego (MACS) - ekspresja antygenu CD133 została wcześniej wykazana w komórkach macierzystych i progenitorowych. Komórki CD133+ różnicowały in vitro w komórki epitelialne i endotelialne. Po implantacji podskórnej myszom SCID komórki te formowały struktury tubularne eksprymujące markery zróżnicowanych komórek nerki. Po podaniu dożylnym myszom SCID, których nerki były uszkodzone w wyniku podania glicerolu, komórki CD133+ migrowały do nerek i zagnieżdżały się w kanalikach nerkowych [36]. Kanaliki nerkowe wydają się więc być niszą dla komórek macierzystych dorosłej nerki. Bombelli i wsp. [37] scharakteryzowali populacje komórek macierzystych jako komórki o fenotypie CD133+/CD24- oraz przejawiające wysoką aktywność enzymu ALDH-1 w stosunku do zróżnicowanych komórek somatycznych nerki. Potwierdzona została więc obecność RSC u osób dorosłych.

\section{ROLA MARKERÓW POWIERZCHNIOWYCH KOMÓREK MACIERZYSTYCH RCC W FIZJOLOGII KOMÓRKI}

Biomarkery molekularne pomagają w planowaniu leczenia, dzięki możliwości dokładniejszego ocenienia m. in. indywidualnego ryzyka progresji choroby i/lub odpowiedzi na określone terapie. Takimi markerami mogą być właśnie białka opisane jako specyficzne dla CSC, gdyż to obecność CSC wydaje się decydować o nawrotach i oporności na terapię nowotworu. Jak już zostało wcześniej zaznaczone, CSC są głównie izolowane na podstawie markerów molekularnych, które mogą odgrywać istotną fizjologiczną rolę w życiu komórki (Tab. 1). Analiza funkcji białek uznawanych za biomarkery molekularne RCC-CSC pozwala wnioskować, że poza znaczeniem diagnostycznym białka te mają także znaczenie dla samego procesu patogenezy RCC, progresji choroby i narastania lekooporności.

\section{CD105}

CD105 (endoglina) jest integralną glikoproteiną błonową, która ulega ekspresji głównie w komórkach endotelialnych naczyń włosowatych, tętnic i żył, jak również w aktywowanych monocytach, niektórych komórkach białaczkowych i syncytiotrofoblaście (wielojądrowych komórkach łożyska, które znacznie zwiększają powierzchnię wymiany składników odżywczych między matką a płodem) [38]. CD105 jest receptorem białek transformującego czynnika wzrostu (ang. transforming growth factor) TGF-1 oraz TGF-3. CD105 indukuje proliferację poprzez ścieżkę sygnałową zależną m.in. od kinazy ALK1 (ang. activin receptor-like kinase 1). Dodatkowo, hipoksja (poprzez HIF-1) stymuluje ekspresję endogliny, podczas gdy aktywacja ścieżki TNF-a hamuje ekspresję CD105. Ścieżka sygnałowa TGF- $\beta$ /Endoglina, aktywowana podczas hipoksji typowo występującej w RCC, hamuje apoptozę poprzez zmniejszanie ekspresji kaspaz 3

Tabela 1. Antygeny CSC i ich znaczenie biologiczne w funkcjonowaniu komórki RCC.

\begin{tabular}{|c|c|}
\hline Białko & Znaczenie biologiczne \\
\hline CD133 (prominina) & $\begin{array}{l}\text { Transbłonowa glikoproteina, pełni ważną rolę w organizacji błony komórkowej, choć niejasna jest jej konkretna } \\
\text { funkcja. W zdrowych komórkach, związane z naprawą tkanki. Komórki CD133+ nie mają właściwości rakotwórczych, } \\
\text { ale znacznie wspomagają wzrost i waskularyzację guza. Nadekspresja CD133 występuje w komórkach } \\
\text { macierzystych hematopoetycznych i śródbłonkowych. Znaczenie w nowotworzeniu nie jest jasne [65]. }\end{array}$ \\
\hline ALDH1 & $\begin{array}{l}\text { Dehydrogenaza aldehydowa. Jest enzymem cytozolicznym. Katalizuje utlenianie aldehydów } \\
\text { do kwasów karboksylowych. Uważany jest za dobry marker CSC [65]. }\end{array}$ \\
\hline CXCR4 & $\begin{array}{l}\text { Receptor a chemokiny SDF-1, która jest związana z przerzutami. Odgrywa rolę w transporcie komórek } \\
\text { macierzystych podczas rozwoju embrionalnego oraz przy uszkodzeniu i regeneracji tkanek }[55,56] \text {. }\end{array}$ \\
\hline CD44 & $\begin{array}{l}\text { CD44 jest receptorem kwasu hialuronowego, który jest glikozoaminoglikanem regulującym proces adhezji } \\
\text { komórkowej, migracji i proliferacji. CD44 utrzymuje równowagę osmotyczną macierzy zewnątrzkomórkowej. Jego } \\
\text { ekspresja jest wyższa w komórkach CSC w porównaniu do innych tkanek, marker komórek nowotworowych [65]. } \\
\text { Fenotyp CD133+ i CD44+ uznaje się za typowy dla komórek macierzystych nabłonka kanalików nerkowych [31]. }\end{array}$ \\
\hline $\begin{array}{l}\text { CAIX (Anhydraza } \\
\text { węglanowa IX) }\end{array}$ & $\begin{array}{l}\text { Katalizuje odwracalną reakcję hydratacji dwutlenku węgla do wodorowęglanu i protonu. Reakcja } \\
\text { ta umożliwia komórkom nowotworowym przetrwanie w kwaśnym mikrośrodowisku, poprzez } \\
\text { utrzymanie obojętnego pH. Brak ekspresji CAIX w zdrowych komórkach nerki [64]. }\end{array}$ \\
\hline
\end{tabular}


i 8. Dokładne mechanizmy molekularne angiogenezy związanej z CD105 nie są w pełni poznane [38]. W badaniach z wykorzystaniem myszy pozbawionych CD105 (nokautów) wykazano, że CD105 odgrywa zasadniczą rolę w angiogenezie, rozwoju naczyń krwionośnych oraz układu krążenia już u wczesnych zarodków myszy [39]. W komórkach endotelialnych wykazano, że endoglina oddziałuje z zyksyną (ang. zyxin), ZRP-1 (ang. zyxin-related protein), tctex $2 b$ (ang. domain-containing protein 2) oraz arestyną (ang. arrestin) i poprzez te interakcje reguluje adhezję, migrację oraz proliferację komórek. Proliferacja indukowana przez endoglinę w komórkach endotelialnych jest nasilana przez ścieżkę sygnałową TGF- $\beta$ /ALK1 i fosforylację białek Smad1/5/8. Kompleks endogliny, T $\beta$ RII oraz ALK1/ ALK2 reguluje fosforylację Ras, a następnie ERK1/2 i w ten sposób wpływa na funkcje komórek [40].

\section{CD133}

CD133 (prominina-1) to białko błonowe o pięciu domenach transbłonowych, którego dokładne funkcje pozostają nadal nie w pełni wyjaśnione i są badane przez liczne zespoły biologów molekularnych. Uważa się, że CD133 jest odpowiedzialna za utrzymanie właściwej topologii błony komórkowej. Interakcje pomiędzy cholesterolem i CD133 sugerują, że CD133 odgrywa istotną rolę w utrzymaniu odpowiedniego stężenia lipidów w obrębie błony komórkowej [41]. CD133 jest markerem hematopoetycznych komórek macierzystych [42]. W zdrowych komórkach białko CD133 jest związane z naprawą tkanek [43]. Przy użyciu macierzy ekspresji tkankowej (ang. tissue expression array) stwierdzono, że mRNA CD133 jest silnie eksprymowane $\mathrm{w}$ tkankach takich jak nerka, gruczoł sutkowy, tchawica, gruczoł ślinowy, łożysko, trzustka, przewód pokarmowy i jądra [44]. W przebiegu nefrogenezy multipotencjalne komórki NCAM1+/CD133- różnicują w komórki progenitorowe NCAM1+/CD133+, które następnie ulegają różnicowaniu w komórki nefronów ICAM1-/CD133+[45].

Najnowsze badania wykazują związek pomiędzy CD133 i beztlenowym metabolizmem komórek, ponieważ CD133 przejawia zdolność inhibicji endocytozy receptora transferyny, co prowadzi do zablokowania wychwytu żelaza, a tym samym prowadzi do obniżenia aktywności fosforylacji oksydacyjnej w mitochondriach [46]. Badania zidentyfikowały CD133 jako marker nowotworowych komórek macierzystych w wielu ludzkich nowotworach [47], jednakże komórki te nie wykazują właściwości guzotwórczych w ksenoprzeszczepach $\mathrm{w}$ raku nerki, natomiast znacznie wspomagają wzrost guza i jego waskularyzację. Istnieją teorie, według których w raku nerkowokomórkowym mikrośrodowisko może rekrutować zdrowe komórki CD133 oraz promować ich włączanie we wzrost guza [48].

\section{ALDH1}

Dehydrogenaza aldehydowa (ALDH1, ALDH1A1) jest enzymem cytozolowym odpowiedzialnym za utlenianie wewnątrzkomórkowych aldehydów do kwasów karboksylowych [49]. ALDH jest obecny w wielu kompartymentach w komórce, chociaż w różnych izoformach - w mitochondriach, cytoplazmie i retikulum endoplazmatycznym. Róż- ne izoformy ALDH1 są rozmieszczone w wielu tkankach, ale najwyższe stężenie zaobserwowano $\mathrm{w}$ wątrobie i w nerkach. Ostatnio stwierdzono, że jedną z głównych funkcji ALDH1 jest katalizowanie przekształcania retinolu do kwasu retinowego i w związku z tym ALDH1 odgrywa także istotną rolę w rozwoju embrionalnym. Ueda i wsp. [50] wykazali, że komórki ALDH1+ posiadają większe zdolności tworzenia guzów i z większą wydajnością formują sfery niż komórki ALDH1-. Ponadto, badania na komórkach ALDH1+ w warunkach hipoksji i ekspozycji na leki wykazały, że komórki ALDH1+ są oporne na terapie konwencjonalnie stosowane przy leczeniu raka nerki [50]. Wysoka aktywność ALDH1 została też opisana w ludzkich oraz mysich komórkach macierzystych i progenitorowych $[51,52]$. Zwiększona aktywność ALDH w populacji komórek macierzystych została zaobserwowana nie tylko w guzach litych, w tym RCC, ale także w szpiczaku mnogim oraz w ostrej białaczce szpikowej. Guzy o zwiększonej aktywności ALDH1 charakteryzują się wysoką lekoopornością $[53,54]$.

\section{CXCR4}

Receptor chemokin typu 4 (CXCR4) jest receptorem dla SDF-1 (ang. a-chemokine stromal-derived factor) i należy do grupy metabotropowych receptorów transbłonowych sprzężonych z białkiem G (ang. G protein-coupled receptors, GPCRs), które są powszechnie eksprymowane w wielu zdrowych komórkach i tkankach, wliczając w to neurony, tkanki limfatyczne oraz komórki hematopoetyczne $[55,56]$. CXCR4 odgrywa ważną rolę w transporcie komórek macierzystych podczas rozwoju, uszkodzenia i regeneracji tkanek. CXCR4 jest związany z przerzutami do kości w przypadku raka piersi i prostaty, poprzez oddziaływanie $\mathrm{z}$ ligandem SDF-1, który odgrywa rolę w tworzeniu guzów i przerzutów. Obniżenie aktywności CXCR4 może okazać się dobrą strategią terapeutyczną w leczeniu białaczek, a także choroby przerzutowej u pacjentów z rakiem, w tym RCC. Strategie terapeutyczne obejmują zarówno leki drobnocząsteczkowe, jak i immunoterapię $[57,58]$.

CD44

CD44 jest glikoproteiną powierzchniowo-transbłonową, pierwotnie zidentyfikowaną na limfocytach. Zewnątrzkomórkowa domena CD44 jest głównym receptorem cząsteczki macierzy zewnątrzkomórkowej, jaką jest kwas hialuronowy. Kwas hialuronowy jest bezsiarczanowym glikozoaminoglikanem, który reguluje procesy adhezji komórkowej, migracji i proliferacji oraz utrzymuje równowagę osmotyczną macierzy zewnątrzkomórkowej poprzez interakcję z receptorem CD44 [59]. Istnieje korelacja pomiędzy nadekspresją kwasu hialuronowego i potencjałem przerzutowym komórek nowotworowych. Zaburzenia oddziaływania komórka-macierz poprzez CD44 są związane z powstawaniem przerzutów i inwazją komórek nowotworowych w organach docelowych przerzutów [60]. CD44 jest białkiem odpowiedzialnym za adhezję komórkową, które wydaje się odgrywać rolę w inwazji komórek nowotworowych oraz w powstawaniu przerzutów, poprzez pośredniczenie $\mathrm{w}$ interakcjach między komórkami nowotworowymi a środowiskiem. Zmieniona ekspresja CD44 w komórkach nowotworowych sugeruje mechanizm prowadzący do 
przerzutowania oraz dodatkowo może dostarczać informacji prognostycznych dla pacjentów (wysoka ekspresja - złe rokowanie).

\section{NCAM}

Cząsteczka adhezji komórek neuronowych (ang. neural cell adhesion molecule, NCAM) należy do nadrodziny immunoglobulin (IgSF) i glikoprotein powierzchniowych komórki. Po raz pierwszy NCAM została wykryta w układzie nerwowym, gdzie odgrywa rolę w zależnej od wapnia adhezji komórkowej. NCAM jest również wskaźnikiem (markerem) neuroendokrynnego różnicowania komórek. Nieindukowane jak i indukowane mezenchymalne komórki nerki płodu eksprymują NCAM - jako specyficzny antygen powierzchniowy komórki - aż do osiągnięcia okresu okołoporodowego. Indukowane komórki mezenchymalne, po przemianie mezenchymalno epitelialnej na niedojrzałych komórkach kanalików podczas rozwoju nefronu, szybko tracą ekspresję NCAM [61]. Ponowna ekspresja NCAM jest wykrywana podczas procesu regeneracji w kanalikach nerkowych [62] jak również w raku jasnokomórkowym nerki oraz przy przerzutach RCC, m.in. do ośrodkowego układu nerwowego (OUN) i nadnerczy [63].

\section{CAIX}

Anhydraza węglanowa IX (CAIX) jest transbłonowym białkiem z rodziny enzymów, które katalizują odwracalną reakcję uwodnienia dwutlenku węgla do wodorowęglanu i protonu. Reakcja ta umożliwia komórkom nowotworowym przetrwanie w kwaśnym mikrośrodowisku poprzez utrzymanie neutralnego $\mathrm{pH}$. CAIX ulega ekspresji w raku jasnokomórkowym nerki, głównie w wyniku indukcji przez HIF1a, co w RCC jest spowodowane warunkami hipoksyjnymi oraz inaktywacją genu VHL. CAIX nie ulega ekspresji w tkankach zdrowej nerki dlatego stanowi dobry marker RCC. Ulega ona także szczególnie wysokiej ekspresji w RCC-CSC których oporność na działanie terapii może m.in. być związana właśnie z funkcją fizjologiczną anhydrazy [64].

\section{INNE PROPONOWANE MARKERY}

Inne potencjalne markery RCC-CSC to $\mathrm{m}$. in. CD24, CD31 oraz CD34. CD24 to glikoproteina powierzchniowa zaangażowana w adhezję i przerzutowanie komórek nowotworowych. Prawdopodobnie odgrywa ona także rolę w angiogenezie [65]. Fenotyp CD133+ i CD24+ uznaje się za typowy dla komórek torebki Bowmana [32]. Z kolei CD31 jest czynnikiem adhezyjnym śródbłonka, eksprymowanym głównie przez płytki krwi i większość subpopulacji leukocytów. Jego ekspresja rośnie przy połączeniach międzykomórkowych. CD31 uczestniczy też w regulacji migracji leukocytów przez ściany żylne, ale w CSC - w tym RCC-CSC - ulega wysokiej ekspresji w guzach litych pomimo niskiej ekspresji w zdrowym organie [66]. Z kolei CD34 jest białkiem błonowym z rodziny sialomucyn, ulegającym wysokiej ekspresji w początkowych stadiach hematopoezy i angiogenezy [67]. Brak ekspresji CD34 jest ważnym czynnikiem przy stwierdzaniu fenotypu komórek mezenchymalnych, a ekspresja wraz z CD133 dla komórek hematopoetycznych i śródbłonkowych oraz RCC-CSC $[68,69]$.

\section{PODSUMOWANIE}

Komórki macierzyste raka nerki (RCC-CSC) pochodzą z tkanki nabłonkowej proksymalnych kanalików nerkowych. Powstają w wyniku mutacji komórek macierzystych, czy też poprzez odróżnicowanie komórek somatycznych nerki i charakteryzują się ekspresją na powierzchni specyficznego zestawu białek. CD105 (endoglina) będąca integralną glikoproteiną błonową, indukuje proliferację poprzez ścieżkę sygnałową zależną od ALK1 (ang. activin receptor-like kinase 1). Z kolei receptor chemokin typu 4 (CXCR4) sprzężonych z białkiem $G$ bierze udział w sygnalizacji komórkowej indukującej migrację komórek. Jednocześnie białko NCAM, będące członkiem nadrodziny immunoglobulin (IgSF) glikoprotein powierzchniowych wydaje się odgrywa rolę $\mathrm{w}$ zależnej od wapnia adhezji komórkowej. Istotnym białkiem w fizjologii RCC-CSC jest także anhydraza węglanowa IX (CAIX), katalizująca odwracalną reakcję uwodnienia dwutlenku węgla do wodorowęglanu i protonu, co umożliwia komórkom przetrwanie w kwaśnym mikrośrodowisku. Istotnymi szlakami sygnałowymi aktywowanymi w komórkach RCC-CSC są szlaki takie jak Hedgehog, Notch, Bmi-1, Wnt, PTEN, Shh i Hox.

\section{PIŚMIENNICTWO}

1. Ridge CA, Pua BB, Madoff DC (2014) Epidemiology and staging of renal cell carcinoma. Semin Intervent Radiol 31: 3-8

2. Gangadaran SGD (2017) Current Management Options in Metastatic Renal Cell Cancer. Oncol Rev 11: 339

3. Motzer RJ, Bacik J, Murphy BA, Russo P, Mazumdar M (2002) Interferon-alfa as a comparative treatment for clinical trials of new therapies against advanced renal cell carcinoma. J Clin Oncol 20: 289-296

4. Brugarolas J (2014) Molecular genetics of clear-cell renal cell carcinoma. J Clin Oncol 32: 1968-1976

5. Czarnecka AM, Szczylik C, Rini B (2014) The use of sunitinib in renal cell carcinoma: where are we now? Expert Rev Anticancer Ther 14: 983-999

6. Bielecka ZF, Czarnecka AM, Solarek W, Kornakiewicz A, Szczylik C (2014) Mechanisms of acquired resistance to tyrosine kinase inhibitors in clear - cell renal cell carcinoma (ccRCC). Curr Signal Transduct Ther 8: $218-228$

7. Gerlinger M, Rowan AJ, Horswell S, Larkin J, Endesfelder D, Gronroos $\mathrm{E}$, et al. (2012) Intratumor heterogeneity and branched evolution revealed by multiregion sequencing. N Engl J Med 366: 883-892

8. Lucarelli G, Galleggiante V, Rutigliano M, Vavallo A, Ditonno P, Battaglia M (2015) Isolation and characterization of cancer stem cells in renal cell carcinoma. Urologia 82: 46-53

9. Dalerba P, Cho RW, Clarke MF (2007) Cancer stem cells: models and concepts. Annu Rev Med 58: 267-284

10. Shuch B, Amin A, Armstrong AJ, Eble JN, Ficarra V, Lopez-Beltran A, et al. (2015) Understanding pathologic variants of renal cell carcinoma: distilling therapeutic opportunities from biologic complexity. Eur Urol 67: 85-97

11. Peired AJ, Sisti A, Romagnani P (2016) Renal cancer stem cells: characterization and targeted therapies. Stem Cells Int 2016: 8342625

12. Seaberg RM, van der Kooy D (2003) Stem and progenitor cells: the premature desertion of rigorous definitions. Trends Neurosci 26: 125-131

13. Bansal N, Banerjee D (2009) Tumor initiating cells. Curr Pharm Biotechnol 10: 192-196

14. Blagosklonny MV (2007) Cancer stem cell and cancer stemloids: from biology to therapy. Cancer Biol Ther 6: 1684-1690

15. Khan MI, Czarnecka AM, Duchnowska R, Kukwa W, Szczylik C (2014) Metastasis-initiating cells in renal cancer. Curr Signal Transduct Ther 8: $240-246$ 
16. Toloudi M, Apostolou P, Chatziioannou M, Papasotiriou I (2011) Correlation between cancer stem cells and circulating tumor cells and their value. Case Rep Oncol 4: 44-54

17. Fazilaty H, Gardaneh M, Bahrami T, Salmaninejad A, Behnam B (2013) Crosstalk between breast cancer stem cells and metastatic niche: emerging molecular metastasis pathway? Tumour Biol 34: 2019-2030

18. Bussolati B, Brossa A, Camussi G (2011) Resident stem cells and renal carcinoma. Int J Nephrol 2011: 286985

19. DeMicco A, Yang-Iott K, Bassing CH (2013) Somatic inactivation of Tp53 in hematopoietic stem cells or thymocytes predisposes mice to thymic lymphomas with clonal translocations. Cell Cycle 12: 33073316

20. Regan JL, Schumacher D, Staudte S, Steffen A, Haybaeck J, Keilholz U, et al. (2017) Non-canonical hedgehog signaling is a positive regulator of the WNT pathway and is required for the survival of colon cancer stem cells. Cell Rep 21: 2813-2828

21. Valenti G, Quinn HM, Heynen G, Lan L, Holland JD, Vogel R, et al. (2017) Cancer stem cells regulate cancer-associated fibroblasts via activation of hedgehog signaling in mammary gland tumors. Cancer Res 77: $2134-2147$

22. Erenpreisa J, Cragg MS (2013) Three steps to the immortality of cancer cells: senescence, polyploidy and self-renewal. Cancer Cell Int 13: 92

23. Zhou N, Lu F, Liu C, Xu K, Huang J, Yu D, et al. (2016) IL-8 induces the epithelial-mesenchymal transition of renal cell carcinoma cells through the activation of AKT signaling. Oncol Lett 12: 1915-1920

24. Takahashi K, Yamanaka S (2006) Induction of pluripotent stem cells from mouse embryonic and adult fibroblast cultures by defined factors. Cell 126: 663-676

25. van de Stolpe A (2013) On the origin and destination of cancer stem cells: a conceptual evaluation. Am J Cancer Res 3: 107-116

26. Masola V, Zaza G, Granata S, Gambaro G, Onisto M, Lupo A (2013) Everolimus-induced epithelial to mesenchymal transition in immortalized human renal proximal tubular epithelial cells: key role of heparanase. J Transl Med 11: 292

27. Kim DH, Xing T, Yang Z, Dudek R, Lu Q, Chen YH (2017) Epithelial mesenchymal transition in embryonic development, tissue repair and cancer: A comprehensive overview. J Clin Med 7:

28. Zhang L, Jiao M, Wu K, Li L, Zhu G, Wang X, et al. (2014) TNF-alpha induced epithelial mesenchymal transition increases stemness properties in renal cell carcinoma cells. Int J Clin Exp Med 7: 4951-498

29. Mizumoto A, Yamamoto K, Nakayama Y, Takara K, Nakagawa T, Hirano T, et al. (2015) Induction of epithelial-mesenchymal transition via activation of epidermal growth factor receptor contributes to sunitinib resistance in human renal cell carcinoma cell lines. J Pharmacol Exp Ther 355: 152-158

30. Bussolati B, Dekel B, Azzarone B, Camussi G (2013) Human renal cancer stem cells. Cancer Lett 338: 141-146

31. Gedye C, Davidson AJ, Elmes MR, Cebon J, Bolton D, Davis ID (2010) Cancer stem cells in urologic cancers. Urol Oncol 28: 585-90

32. Axelson H, Johansson ME (2013) Renal stem cells and their implications for kidney cancer. Semin Cancer Biol 23: 56-61

33. Grange C, Tapparo M, Collino F, Vitillo L, Damasco C, Deregibus MC, et al. (2011) Microvesicles released from human renal cancer stem cells stimulate angiogenesis and formation of lung premetastatic niche. Cancer Res 71: 5346-5356

34. Chen G, Zhang Y, Wu X (2014) 786-0 Renal cancer cell line-derived exosomes promote 786-0 cell migration and invasion in vitro. Oncol Lett 7: 1576-1580

35. Gupta S, Verfaillie C, Chmielewski D, Kren S, Eidman K, Connaire J, et al. (2006) Isolation and characterization of kidney-derived stem cells. J Am Soc Nephrol 17: 3028-3040

36. Bussolati B, Bruno S, Grange C, Buttiglieri S, Deregibus MC, Cantino $\mathrm{D}$, et al. (2005) Isolation of renal progenitor cells from adult human kidney. Am J Pathol 166: 545-555

37. Bombelli S, Zipeto MA, Torsello B, Bovo G, Di Stefano V, Bugarin C, et al. (2013) PKH(high) cells within clonal human nephrospheres provide a purified adult renal stem cell population. Stem Cell Res 11:1163-1177
38. Warrington K, Hillarby MC, Li C, Letarte M, Kumar S (2005) Functional role of CD105 in TGF-beta1 signalling in murine and human endothelial cells. Anticancer Res 25: 1851-1864

39. Li C, Hampson IN, Hampson L, Kumar P, Bernabeu C, Kumar S (2000) CD105 antagonizes the inhibitory signaling of transforming growth factor beta1 on human vascular endothelial cells. FASEB J 14: 55-64

40. Valluru M, Staton CA, Reed MW, Brown NJ (2011) Transforming growth factor-beta and endoglin signaling orchestrate wound healing. Front Physiol 2: 89

41. Mizrak D, Brittan M, Alison M (2008) CD133: molecule of the moment. J Pathol 214: 3-9

42. Yin AH, Miraglia S, Zanjani ED, Almeida-Porada G, Ogawa M, Leary AG, et al. (1997) AC133, a novel marker for human hematopoietic stem and progenitor cells. Blood 90: 5002-5012

43. Bussolati B, Collino F, Camussi G (2012) CD133+ cells as a therapeutic target for kidney diseases. Expert Opin Ther Targets 16: 157-165

44. Florek M, Haase M, Marzesco AM, Freund D, Ehninger G, Huttner WB, et al. (2005) Prominin-1/CD133, a neural and hematopoietic stem cell marker, is expressed in adult human differentiated cells and certain types of kidney cancer. Cell Tissue Res 319: 15-26

45. Pode-Shakked N, Pleniceanu O, Gershon R, Shukrun R, Kanter I, Bucris E, et al. (2016) Dissecting stages of human kidney development and tumorigenesis with surface markers affords simple prospective purification of nephron stem cells. Sci Rep 6: 23562

46. Bourseau-Guilmain E, Griveau A, Benoit JP, Garcion E (2011) The importance of the stem cell marker prominin-1/CD133 in the uptake of transferrin and in iron metabolism in human colon cancer Caco-2 cells. PLoS One 6: e25515

47. Neuzil J, Stantic M, Zobalova R, Chladova J, Wang X, Prochazka L, et al. (2007) Tumour-initiating cells vs. cancer 'stem' cells and CD133: what's in the name? Biochem Biophys Res Commun 355: 855-859

48. Bruno S, Bussolati B, Grange C, Collino F, Graziano ME, Ferrando U, et al. (2006) CD133+ renal progenitor cells contribute to tumor angiogenesis. Am J Pathol 169: 2223-2235

49. Douville J, Beaulieu R, Balicki D (2009) ALDH1 as a functional marker of cancer stem and progenitor cells. Stem Cells Dev 18: 17-25

50. Ueda K, Ogasawara S, Akiba J, Nakayama M, Todoroki K, Sanada S, et al. (2013) Aldehyde dehydrogenase 1 identifies cells with cancer stem cell-like properties in a human renal cell carcinoma cell line. PLoS One 8: e75463

51. Hess DA, Wirthlin L, Craft TP, Herrbrich PE, Hohm SA, Lahey R, et al. (2006) Selection based on CD133 and high aldehyde dehydrogenase activity isolates long-term reconstituting human hematopoietic stem cells. Blood 107: 2162-2169

52. Seneviratne AK, Bell GI, Sherman SE, Cooper TT, Putman DM, Hess DA (2016) Expanded Hematopoietic Progenitor Cells Reselected for High Aldehyde Dehydrogenase Activity Demonstrate Islet Regenerative Functions. Stem Cells 34: 873-887

53. Shiraishi A, Tachi K, Essid N, Tsuboi I, Nagano M, Kato T, et al. (2017) Hypoxia promotes the phenotypic change of aldehyde dehydrogenase activity of breast cancer stem cells. Cancer Sci 108: 362-372

54. Bogen A, Buske C, Hiddemann W, Bohlander SK, Christ O (2017) Variable aldehyde dehydrogenase activity and effects on chemosensitivity of primitive human leukemic cells. Exp Hematol 47: 54-63

55. Skommer J, Wlodkowic D, Pelkonen J (2007) CXCR4 expression during tumour cell death. Leuk Res 31: 1155-1156

56. Teixido J, Martinez-Moreno M, Diaz-Martinez M, Sevilla-Movilla S (2017) The good and bad faces of the CXCR4 chemokine receptor. Int J Biochem Cell Biol 95: 121-131

57. Tsou LK, Huang YH, Song JS, Ke YY, Huang JK, Shia KS (2017) Harnessing CXCR4 antagonists in stem cell mobilization, HIV infection, ischemic diseases, and oncology. Med Res Rev 38: 1188-1234

58. Santagata S, Napolitano M, D'Alterio C, Desicato S, Maro SD, Marinelli L, et al. (2017) Targeting CXCR4 reverts the suppressive activity of T-regulatory cells in renal cancer. Oncotarget 8: 77110-77120 
59. Karousou E, Misra S, Ghatak S, Dobra K, Gotte M, Vigetti D, et al. (2017) Roles and targeting of the HAS/hyaluronan/CD44 molecular system in cancer. Matrix Biol 59: 3-22

60. Tawfik OW, Kramer B, Shideler B, Danley M, Kimler BF, Holzbeierlein J (2007) Prognostic significance of CD44, platelet-derived growth factor receptor alpha, and cyclooxygenase 2 expression in renal cell carcinoma. Arch Pathol Lab Med 131: 261-267

61. Nouwen EJ, Dauwe S, van der Biest I, De Broe ME (1993) Stage- and segment-specific expression of cell-adhesion molecules N-CAM, A-CAM, and L-CAM in the kidney. Kidney Int 44: 147-158

62. Abbate M, Brown D, Bonventre JV (1999) Expression of NCAM recapitulates tubulogenic development in kidneys recovering from acute ischemia. Am J Physiol 277: F454-F463

63. Daniel L, Bouvier C, Chetaille B, Gouvernet J, Luccioni A, Rossi D, et al. (2003) Neural cell adhesion molecule expression in renal cell carcinomas: relation to metastatic behavior. Hum Pathol 34: 528-532

64. Tostain J, Li G, Gentil-Perret A, Gigante M (2010) Carbonic anhydrase 9 in clear cell renal cell carcinoma: a marker for diagnosis, prognosis and treatment. Eur J Cancer 46: 3141-3148
65. Baillie R, Tan ST, Itinteang T (2017) Cancer stem cells in oral cavity squamous cell carcinoma: A review. Front Oncol 7: 112

66. Woodfin A, Voisin MB, Nourshargh S (2007) PECAM-1: a multi-functional molecule in inflammation and vascular biology. Arterioscler Thromb Vasc Biol 27: 2514-2523

67. Nielsen JS, McNagny KM (2008) Novel functions of the CD34 family. J Cell Sci 121: 3683-3692

68. Otto W, Król M, Maciaszczyk M, Sierdziński J, Najnigier B, Krawczyk M (2013) Identification and significance of circulating endothelial progenitor cells in patients with hepatocellular carcinoma. Nowotwory 63: 383-394

69. Pojda Z, Machaj E, Kurzyk A, Mazur S, Dębski T, Gilewicz J, et al. (2013) Mezenchymalne komórki macierzyste. Postępy Biochem 59: 187-197

70.Sanz-Rodriguez F, Guerrero-Esteo M, Botella LM, Banville D, Vary CP, Bernabeu C (2004) Endoglin regulates cytoskeletal organization through binding to ZRP-1, a member of the Lim family of proteins. J Biol Chem 279: 32858-32868

\title{
Cancer stem cells in renal carcinoma
}

\section{Łukasz Szymański ${ }^{1,2 \& a}$, Igor Helbrecht ${ }^{1,22 \notin}$, Michał Fiedorowicz ${ }^{3 \rrbracket}$, Damian Matak ${ }^{1,4,}$, Ewa Bartnik ${ }^{2,5}$, Paweł Golik ${ }^{2,5}$, Cezary Szczylik ${ }^{1,4, b, c}$, Anna M. Czarnecka ${ }^{1, d, e}$}

\author{
${ }^{1}$ Department of Oncology with Laboratory of Molecular Oncology, Military Institute of Medicine, Warsaw, Poland \\ ${ }^{2}$ Faculty of Biology, Institute of Genetics and Biotechnology, University of Warsaw, Warsaw, Poland \\ ${ }^{3}$ Mossakowski Medical Research Centre, Polish Academy of Sciences, Warsaw, Poland \\ ${ }^{4}$ School of Molecular Medicine, Medical University of Warsaw, Warsaw, Poland \\ ${ }^{5}$ Institute of Biochemistry and Biophysics, Polish Academy of Sciences, Warsaw, Poland \\ \&authors contributed equally

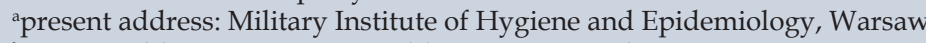 \\ ${ }^{\mathrm{b}}$ present address: European Health Centre, Otwock \\ cpresent address: Centre of Postgraduate Medical Education, Warsaw \\ dpresent address: Mossakowski Medical Research Centre, Polish Academy of Sciences, Warsaw \\ epresent address: Department of Soft Tissue/Bone Sarcoma and Melanoma, Maria Sklodowska-Curie Institute - Oncology Center, Warsaw \\ $\llbracket$ To whom the correspondence should be addressed: mfiedorowicz@imdik.pan.pl
}

Keywords: renal cancer, stem cells, CD105, CD133

\begin{abstract}
Cancers account for $85 \%$ of renal tumors. In Poland renal cancer is diagnosed in almost four thousands patients every year and two thousands of them dies. The most common subtype of renal cancer is clear cell renal cell carcinoma (ccRCC), which accounts for $80-90 \%$ of all renal cancer cases. ccRCC is resistant to chemo- and radiotherapy. More and more data suggest that tumor growth is a result of proliferation and differentiation of a small population of cells called cancer stem cells (CSC). CSCs are responsible for tumor progression and for the resistance to chemo- and radiotherapy. This publication covers the role the CSCs and their origin in renal cell carcinoma, with particular emphasis on clear cell subtype.
\end{abstract}

